\title{
Insights on the opening of the Galerian mammal migration pathway from magnetostratigraphy of the Pleistocene marineecontinental transition in the Arda River section (northern Italy)
}

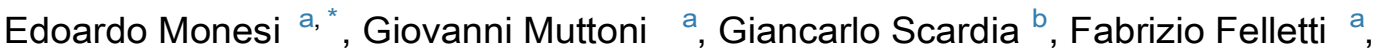 \\ Fabio Bona ${ }^{a, c}$, Benedetto Sala ${ }^{d}$, Fabrizio Tremolada ${ }^{e}$, Carlo Francou ${ }^{c}$, Gianluca Raineri ${ }^{f}$ \\ a Dipartimento di Scienze della Terra, Universita di Milano, via Mangiagalli 34, I-20133, Milano, Italy \\ ${ }^{b}$ Instituto de Geociencias e Cências Exatas,Universidade Estadual Paulista,Rio Claro, SP, 13506-900Brazil \\ ' Museo Geologico “G.Cortesi”, via Sforza Caolzio 57,29014, Castell'Arquato, Italy \\ ${ }^{d}$ Museo di Paleontologia e Preistoria, Universita degli Studi di Ferrara, Corso Ercole I d'Este 32,44121, Ferrara, Italy

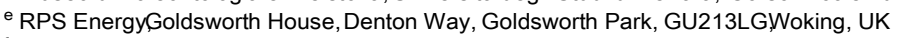 \\ ${ }^{f}$ Ente di Gestione dei Parchi dell'Emilia Occidentale,Piazza G.Ferrari 5, 43013, Langhiano, Italy
}

\begin{abstract}
a bstract
We investigated the magnetostratigraphy of the Arda River section (northern Italy) where the transition from marine to continental sedimentation occurring in the Po River basin during the Pleistocene is registered. Four magnetic polarity reversals were used to construct an age model of sedimentation aided by marine biostratigraphy and tied to a standard $\quad \mathrm{d}^{18} \mathrm{O}$ curve from the literature. The section spans from the Olduvai subchron (1.94e1.78 Ma) across the Jaramillo subchron (1.07e0.99 Ma) up to the Brunhes eMatuyama boundary $(0.78 \mathrm{Ma})$. The onset of continental deposition occurred during marine isotope stage (MIS) 30 at $\sim 1.04 \mathrm{Ma}$. An association of Villafranchian and Early Galerian mammals, including Sus strozzii and Ursus dolinensis, has been found in the continental sediments dated to MIS 29e27 ( 0.99 Ma). Above follows a prominent fluvial conglomerate attributed to the first major lowstand of the Pleistocene culminating with MIS 22 at $\sim 0.9$ Ma during the late Early Pleistocene climate turnover (EPT). These and other data from the literature are used to reconstruct the onset of continental deposition in the greater Po basin and shed light on the opening of the migration pathway that brought far-traveled Galerian mammal immigrants to enter Europe for the first time during the EPT.
\end{abstract}

Introduction

The Arda River section is located in northern Italy near the town of Castell'Arquato at the margin of the northern Apennines facing the Po River plain (Fig. 1). The section consists of a thick and continuous record of the transition from marine sedimentation typical of the PlioceneeEarly Pleistocene to late Early PleistoceneeHolocene continental sedimentation, as documented in part also in the adjacent Stirone and Enza river sections (Mary et al., 1993; Gunderson et al., 2012, 2013; 2014).

Our main objective is to generate an age model of sedimentation for the Arda River section by integrating magnetostratigraphy (this study) with marine biostratigraphic data (Crippa et al., 2016; this

\footnotetext{
${ }^{*}$ Corresponding author.

E-mail address: edoardo.monesi@unimi.it (E. Monesi).
}

study). In particular, we aim at dating the onset of continental deposition recorded in the upper part of the section where we also found a new mammal association (see also Bona and Sala, 2016). We use magnetostratigraphy to correlate the Arda River section to other sections from the literature (Muttoni et al., 2003, 2011; Scardia et al., 2006; Gunderson et al., 2012; Scardia et al., 2012; Gunderson et al., 2014; Pinti et al., 2001) with the objective of gauging how the onset of continental deposition evolved in space and time across the greater Po River basin. The timing of full continentalization of the Po basin is thought to coincide with the arrival in Europe of a renewed mammal fauna (Galerian) characterized by far-traveled immigrant species (Palombo and Mussi, 2006; Muttoni et al., 2014, 2015a; Palombo, 2014). We hypothesize that this was brought on by the formation of vast and exploitable ecosystems along a newly formed continental Po (and Danube) migration pathway, as recently described in Muttoni et al. $(2014,2015 a)$ and further explored in this paper. 


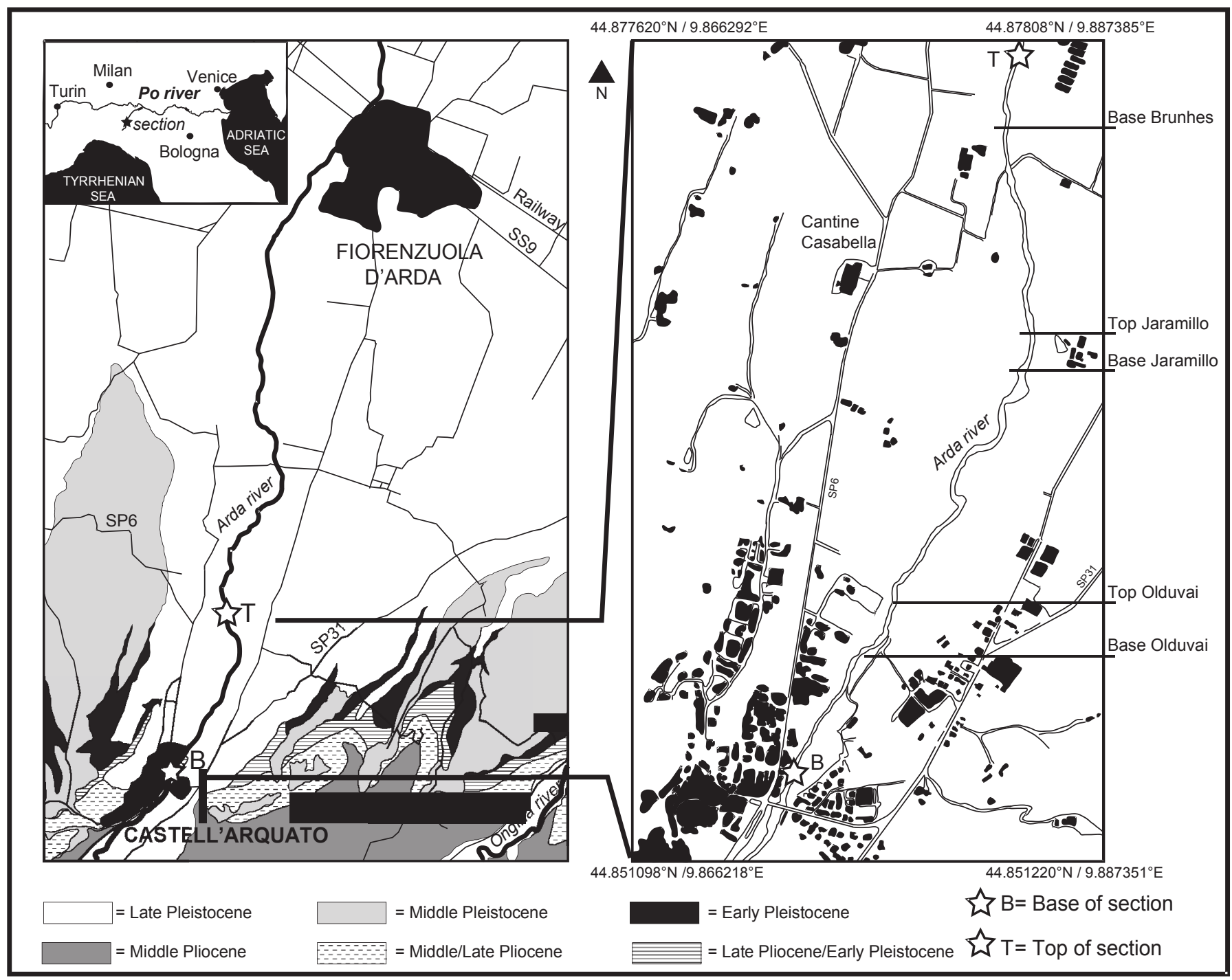

Figure 1. In left panel, geological map of the Castell'Arquato area in the northern Apennines with indication of the Arda River section. section with location of the main magnetic polarity reversals. Contour lines have been removed in both panels for clarity.

\section{Stratigraphy and sedimentology}

The Pleistocene Arda River section of this study lies stratigraphically above the Pliocene Castell'Arquato section of Channell et al. (1994), this latter comprised of marine claystones ('Argille Azzurre' Auctorum) correlated by biostratigraphy to the nearby Stirone section that was magnetostratigraphically dated from the Gilbert Chron at $\sim 5 \mathrm{Ma}$ to the Gauss Chron at $\sim 2.5 \mathrm{Ma}$ (Mary et al., 1993; Channell et al., 1994).

The Arda River section starts at the bridge immediately to the north of Castell'Arquato (base: $44.853619 \quad$ N/9.873154 E) and extends northward along the banks of the Arda River for 300 stratigraphic meters (top: 44.877505 N/9.883693 E) (Fig. 1). The stratigraphic succession of marine-transitionalecontinental deposits therein exposed are attributed in the Italian Geological Map (Calabrese et al., 2009) to the Badagnano Synthem (mainly marine sandstones and claystones) and the Torrente Stirone and Costamezzana Synthems (mainly littoral sandstones, lagoonal/continental silty claystones, and fluvial conglomerates). Strata gently dip to the north by $\sim 10$ at the base and 5 e6 at the top. Faults have been observed in the lower part of the section up to $\sim 50 \mathrm{~m}$ (Fig. 2A).
From bottom to top, five lithozones have been distinguished and interpreted in terms of depositional environment:

Lithozone $1(0 \mathrm{e} 220 \mathrm{~m})$ consists of marine conglomerates and sandstones arranged in at least six, $5 \mathrm{e} 25 \mathrm{~m}$-thick fining upward cycles (labeled leVI in Fig. 2A) interpreted as high-density turbidite flows (sensu Mutti et al., 2000). Each turbidite flow usually starts with massive to cross-bedded conglomerates with abundant shallow-water skeletal remains and intraclasts. Above follow sandstones that are either massive or with horizontal, hummocky, tabular or oblique cross stratification. Sharp-based, normally graded, tabular to lenticular lags of concave-down shells may occur at the base of the strata. Carbonaceous remains and wood fragments are also common within massive turbidite sandstones. Flaser and massive mudstone beds up to several $\mathrm{cm}$-thick are often intercalated with these sandstones. Finally, above the turbidite sandstones follow resedimented, massive to laminated siltstones and mudstones arranged in thin couplets. Each of these turbidite events (leVI) grade into hemipelagic siltstones and mudstones with marine bivalves in life position. The first occurrence of the foraminifera Hyalinea baltica and of the bivalve Arctica islandica were recorded at $98.3 \mathrm{~m}$ (Crippa et al., 2016) and $103 \mathrm{~m}$, respectively. 


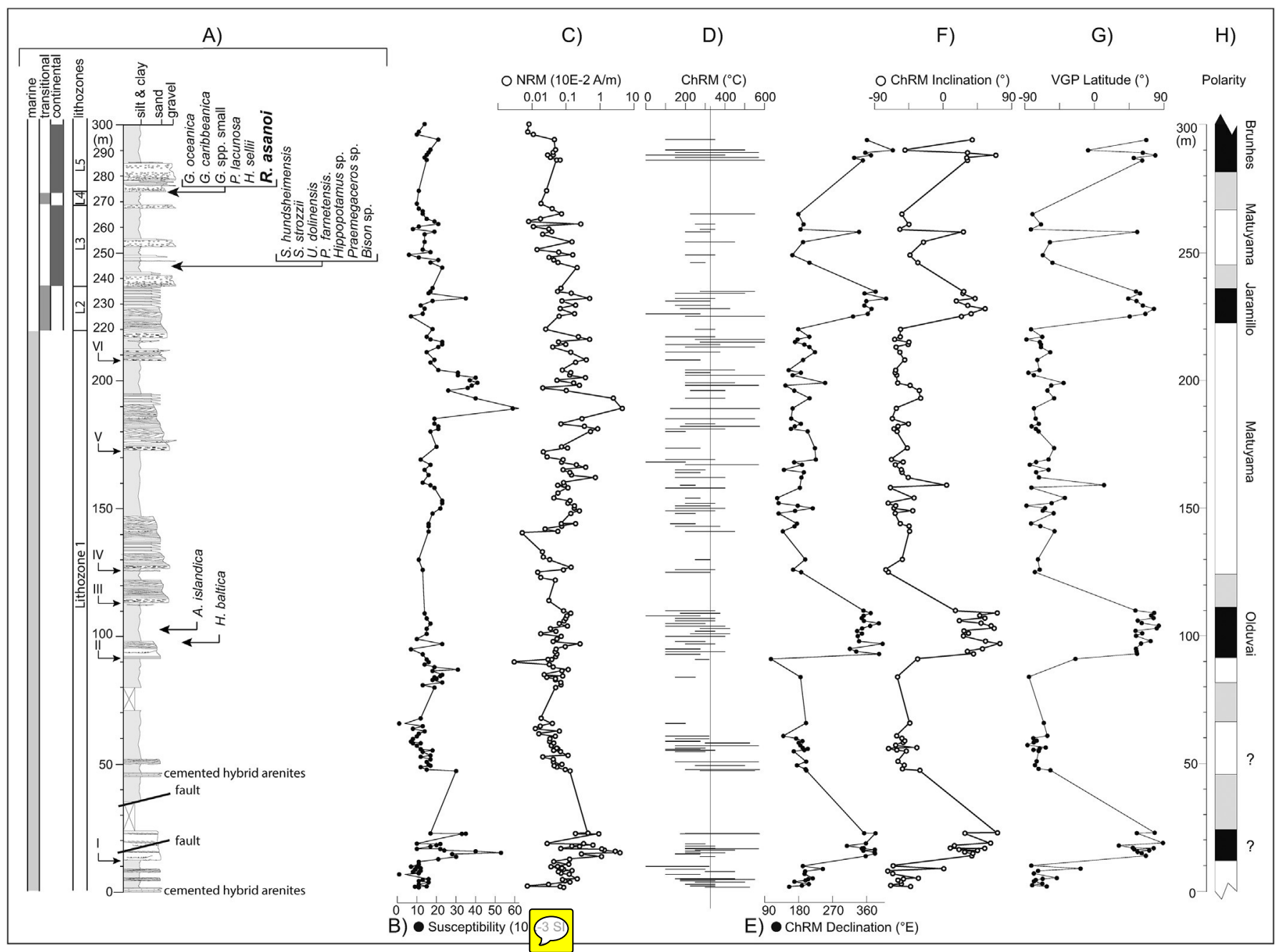

Figure 2. Stratigraphy and paleomagnetic data of the Arda River section. $\quad$ A) Stratigraphic sequence and key fossil occurrences; B) magnetic susceptibility; C) natural remanent magnetization (NRM); D) demagnetization window of the characteristic remanent magnetization (ChRM); E and F) declination and inclination of the ChRM; G) latitude of the virtual geomagnetic pole (VGP) of the ChRM; H) magnetic polarity, where black is normal and white is reverse polarity. L2 $1 / 4$ lithozone 2 ; L3 $1 / 4$ lithozone 3 ; L4 1/4 lithozone 4 ; L5 $\frac{1}{4}$ lithozone 5 .

Lithozone $2(220 \mathrm{e} 237 \mathrm{~m})$ is characterized by $0.3 \mathrm{e} 1 \mathrm{~m}$-thick beds of coarse-grained sandstones and matrix supported pebbly sandstones with low-angle (20 ) cross-stratification trending asymptotically to the top and base of the beds, attributed to littoral (transitional) environments (Fig 2A). The top of lithozone 2 at $237 \mathrm{~m}$ represents the top of the section studied for biostratigraphy by Crippa et al. (2016) with an estimated age of $\sim 1.1 \mathrm{Ma}$ based on nannofossils.

Lithozone $3(237 \mathrm{e} 269 \mathrm{~m})$ is comprised of continental sediments arranged in four main cycles, each characterized by $1 \mathrm{e} 4 \mathrm{~m}$-thick massive or crudely stratified, partially cemented fluvial gravel beds, passing rapidly upward to sandstones, siltstones and mudstones. Fossil roots and trunks in in-life position, together with calcium carbonate nodules and freshwater gastropods, are frequent in finegrained beds, suggesting continental swamp environments. A level with mammal bones attributed to Sus strozzii, Stephanorhinus hundsheimensis, Ursus dolinensis, Pseudodama farnetensis, Bison sp., Hippopotamus sp., and Praemegaceros sp. has been found at $245 \mathrm{~m}$ (Fig. 2A; see also discussion below).

Lithozone $4(269 \mathrm{e} 275 \mathrm{~m})$ consists of marine-transitional silty claystones bearing (mostly reworked) nannofossils with, among others, the useful marker Reticulofenestra asanoi (Fig. 2A; see discussion below). Finally, lithozone 5 follows above with persistent continental sedimentation consisting mainly of fluvial sands and gravels (Fig. 2A), which continues above our stratigraphic log with the deposition during the MiddleeLate Pleistocene of the fluvial gravels of the Emilia Romagna Supersynthem (Calabrese et al., 2009).

\section{Mammal fauna}

The mammal fauna found at $245 \mathrm{~m}$ consists of 61 bone and teeth remains retrieved in $2006 \mathrm{e} 2015$ and housed at the geological museum "G. Cortesi" of Castell'Arquato. The fauna consists of seven taxa attributed using specific morphological features described hereafter and in a parallel paper (Bona and Sala, 2016): (I) S. hundsheimensis (Fortelius et al., 1993; Lacombat, 2006), attribution based on the overall morphology and dimensions of the skull and the teeth (Fig. 3, panel 1). (II) Sus strozzii, attribution based on the mandibular canines that present the typical 'Sus verrucosus ' section (Azzaroli, 1954) where buccal and lingual sides are similar in breadth while the distal side is less developed and the section of the teeth resembles an isosceles triangle (Fig. 3, panel 2). (III) U. dolinensis, attribution based on the skull and jaw that show strong speloid-like development while the teeth display very simple arctoid-like shapes and medium to large size dimensions (Fig. 3, panels 3e4). U. dolinensis was first described by García and Arsuaga (2001) at Atapuerca in Spain, while according to García (2004) and 


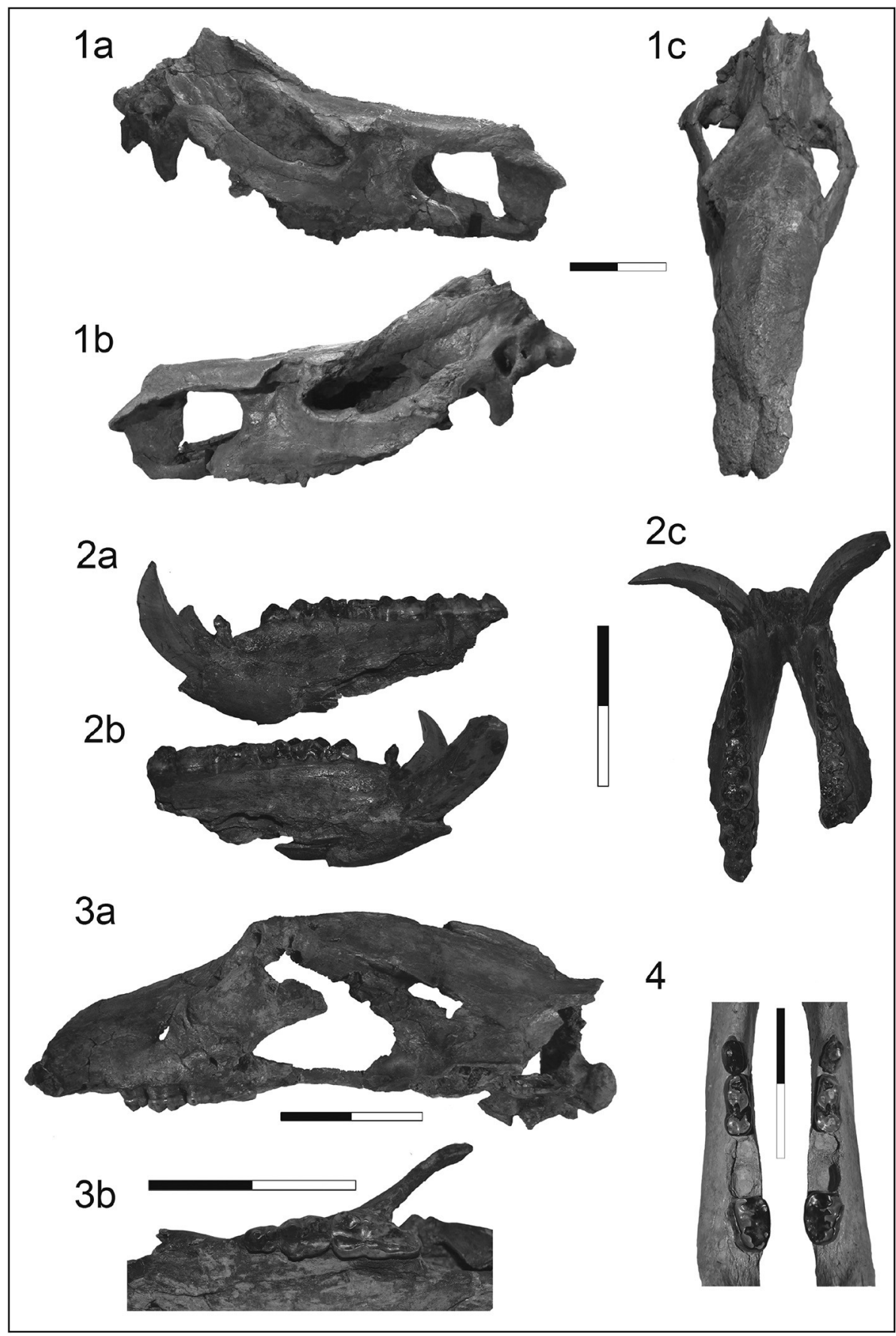

Figure 3. Key mammals from the Arda River section. 1) Stephanorhinus hundsheimensis: skull (Vt 088) aeright side, beleft side, cedorsal view; 2) Sus strozzii: mandible (Vt 090) aeleft side, beright side, ceocclusal view; 3) Ursus dolinensis: half skull (Vt 081) aeleft side, beleft cheek teeth; 4) Ursus dolinensis: mandible (Vt 034, Vt 035) occlusal view. Scale bar $1 / 410 \mathrm{~cm}$.

Kahlke (2007), Ursus rodei from Untermassfeld in Germany (Musil, 2001) should be considered a junior equivalent of U. dolinensis. (IV) P.farnetensis, attribution based on the overall morphology and dimensions of the teeth and the position of the brow tine close to the burr. (V) Hippopotamus sp., whose remains consist of only two large femur diaphyses with sub-square sections pertaining to two young individuals. (VI) Praemegaceros sp.indet., attribution based on the development direction of the peduncles observed in the frontal bones of a fragmentary skull, which forms a typical angle of about 90 (Kostopoulos, 1997; Azzaroli and Mazza, 1992). (VII) Bison sp., attribution based on the large dimensions of the bones and the degree of hypsodonty, as well as the slightly swollen base of the teeth crowns (Sala, 1986); the lack of a skull with horns and the fragmentary condition of the distal bones do not allow a more accurate species identification.

The Arda faunal assemblage comprises taxa included in the Villafranchian mammal age, such as Pseudodama and Sus strozzii, co-existing with the large cervid Praemegaceros and the bear $U$. dolinensis $(1 / 4 \mathrm{U}$. rodei), which are commonly considered postVillafranchian and pertaining to the beginning of the Galerian mammal age (Gliozzi et al., 1997; Kahlke, 2007; Masini and Sala, 2007). Bison sp. and Hippopotamus sp. are not particularly 


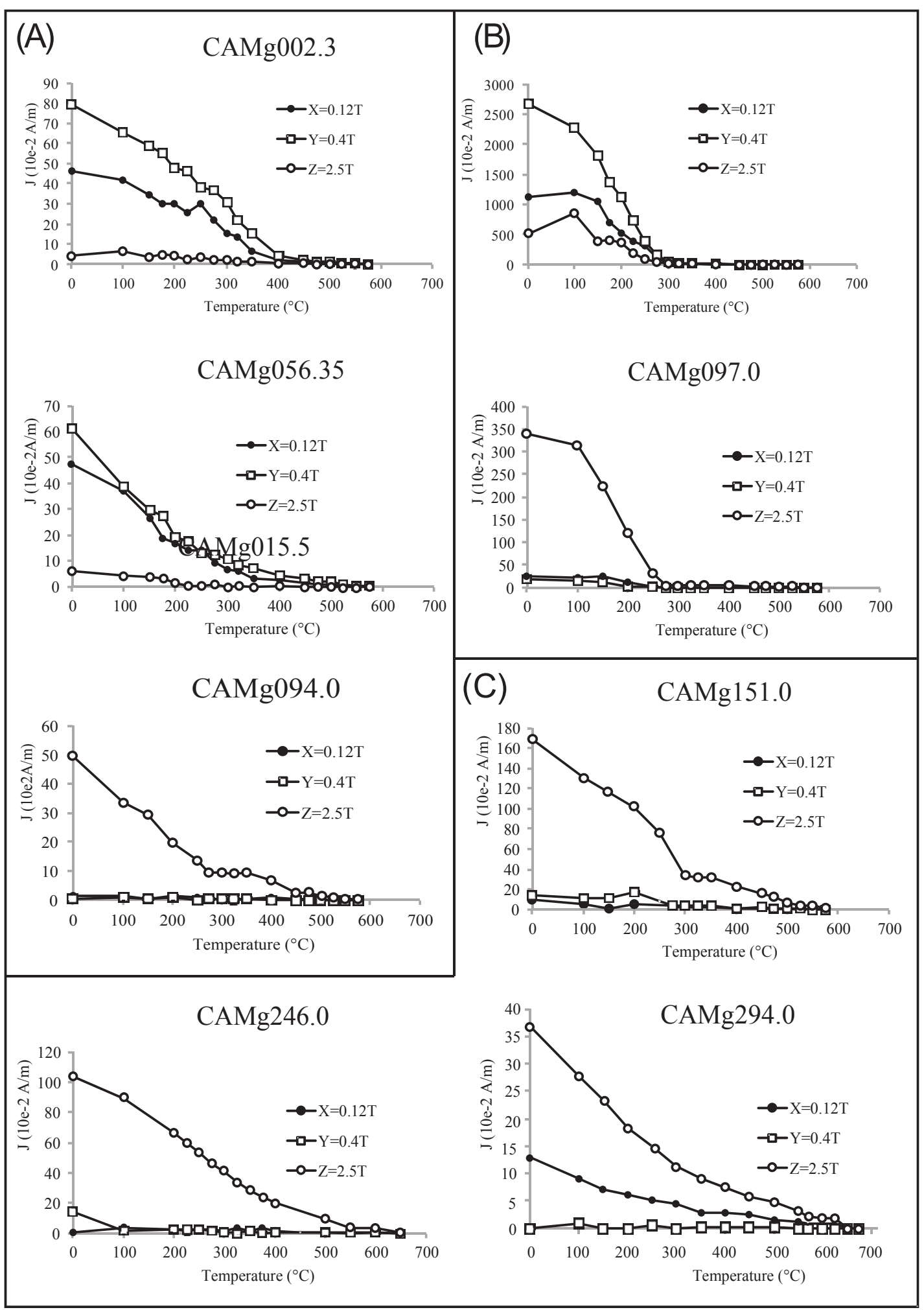

Figure 4. Isothermal remanent magnetization (IRM) diagrams of representative samples from the Arda River section bearing dominant (titano)magnetite (A), and hematite $(C)$; see text for discussion.

diagnostic in terms of mammal age attribution because the former could not been identified at sub-generic (Eobison or Bison) or specific level, and the latter belongs to a genus that has a wide temporal distribution (Gliozzi et al., 1997; Masini and Sala, 2007). In any case, according to the presence of the large-sized cervid
Praemegaceros sp.,the Arda fauna can be attributed to the Early Galerian Colle Curti faunal unit (FU) (Gliozzi et al., 1997; Coltorti et al., 1998; Masini and Sala, 2007). Elsewhere in Europe, a similar fauna was found at Untesmassfeld in Germany (Kahlke, 2006; Maul and Markova, 2007; Kahlke et al., 2011). 


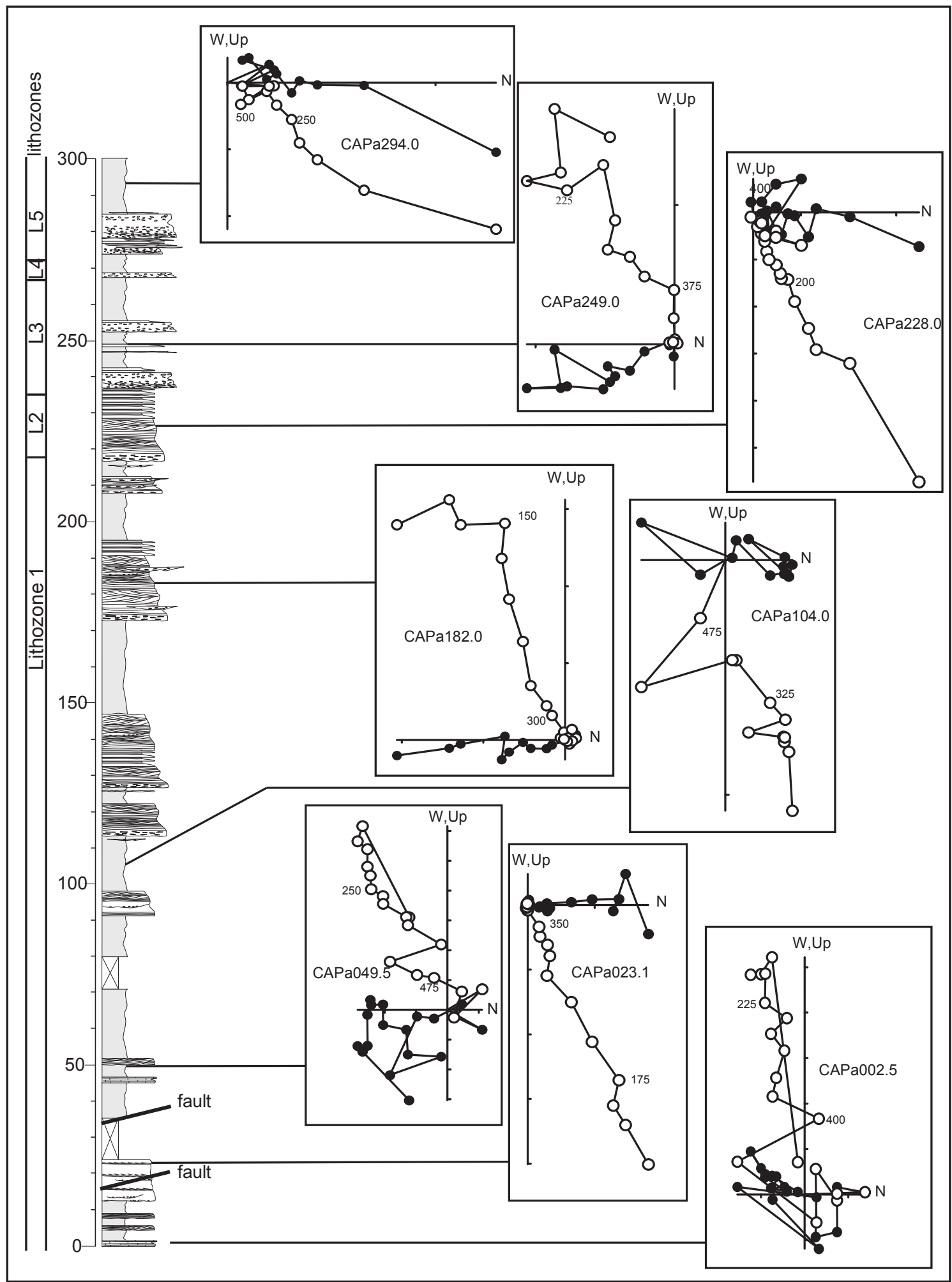

Figure 5. Vector end-point demagnetization diagrams of representative samples plotted aside the Arda stratigraphic sequence. Full symbols are projections on the horizontal plane and open symbols on the vertical plane. Demagnetization temperatures are expressed in $\quad$ C. L2 $1 \frac{1}{4}$ lithozone 2; L3 $1 / 4$ lithozone 3 ; L4 $1 / 4$ lithozone 4 ; L5 $1 / 4$ lithozone 5.

\section{Paleomagnetic methods}

Paleomagnetic samples were cored in the field with an electric drill and oriented with a magnetic compass to obtain a total of 214 standard $\left(10 \mathrm{~cm}^{3}\right)$ cylindrical specimens for paleomagnetic analyses. The initial magnetic susceptibility was measured on all samples at room temperature with a MS2 Bartington susceptibility bridge. A sub-set of 29 samples was subjected to rock magnetic analyses by means thermal demagnetization of a three-component isothermal remanent magnetization (IRM) imparted in fields of 


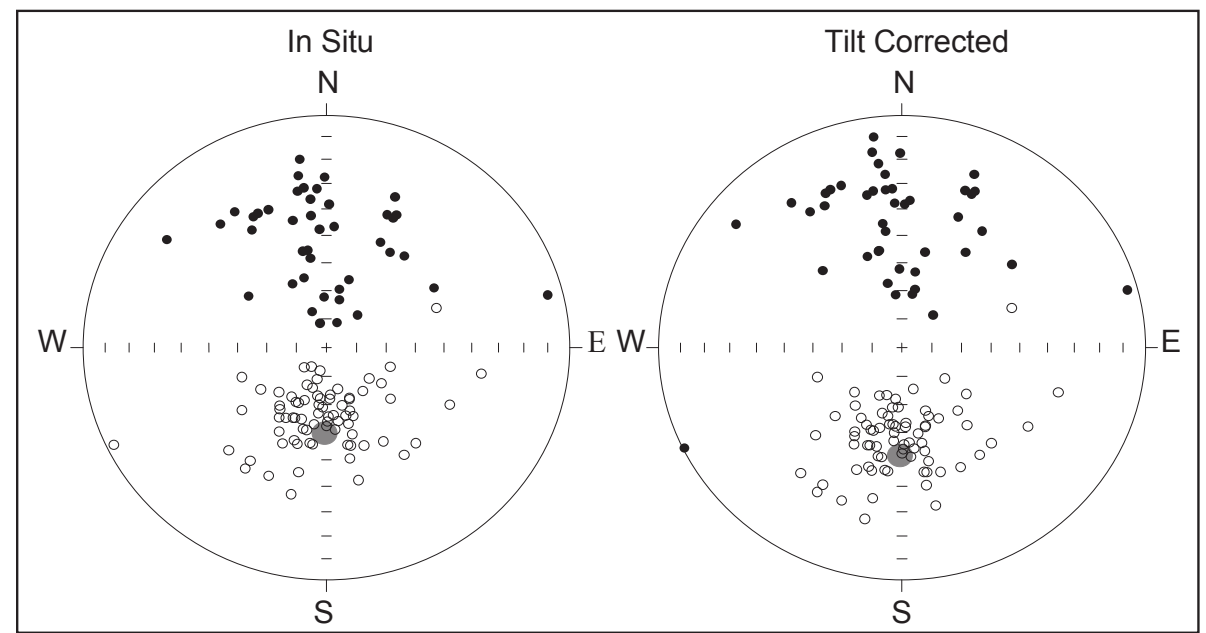

Figure 6. Equal area projection of the ChRM component directions in in situ and tilt corrected coordinates. symbols represent up-pointing vectors (reverse polarity).

Full symbols represent down-pointing vectors (normal polarity),

$2.5 \mathrm{~T}, 0.4 \mathrm{~T}$, and $0.12 \mathrm{~T}$. The remaining 185 samples were subjected to thermal demagnetization in steps of 50 or 25 C from room temperature up to the Curie points of the magnetic minerals therein contained using a ASC TD48 furnace. The natural remanent magnetization (NRM) was measured after each demagnetization step with a 2 G Enterprises DC-SQUID cryogenic magnetometer located in a shielded room. Standard least-square analysis was used to calculate magnetic component directions from vector end-point demagnetization diagrams, and standard Fisher statistical analysis was used to analyze the mean component directions. Magnetic measurements were carried out at the Alpine Laboratory of Paleomagnetism of Peveragno (Italy).

\section{Paleomagnetic results}

The magnetic susceptibility is characterized by values of $\sim 10 \mathrm{e} 20^{*} 10^{3-} \mathrm{SI}$ with two peaks of $\sim 50 \mathrm{e} 60^{*} 10^{3-} \mathrm{SI}$ at $17 \mathrm{~m}$ and $187 \mathrm{~m}$ (Fig. 2B). The intensity of the NRM shows average values of $\sim 0.07^{*} 10^{2} \quad \mathrm{~A} / \mathrm{m}$ and two peaks of $\sim 4 \mathrm{e}^{*} 10^{2} \mathrm{~A} / \mathrm{m}$ across the same stratigraphic levels as the susceptibility peaks (Fig. 2C).

Stepwise thermal demagnetization experiments of a threecomponent IRM show three types of behaviors: (I) the intermediate $(0.4 \mathrm{~T})$ and sometimes also the low $(0.12 \mathrm{~T})$ coercivity curves show maximum unblocking temperatures in excess of $\sim 400 \quad \mathrm{C}$ and sometimes up to $\sim 570 \mathrm{C}$, interpreted as signaling the presence of (titano)magnetite (Fig. 4A). (II) The intermediate $(0.4 \mathrm{~T})$ and sometimes also the low $(0.12 \mathrm{~T})$ and high $(2.5 \mathrm{~T})$ coercivity curves show a drastic drop in intensity at $\sim 275 \mathrm{e} 300 \quad \mathrm{C}$ interpreted as due to the presence of iron sulphides (Fig. 4B). (III) The high (2.5 T) coercivity curve shows maximum unblocking temperatures up to $\sim 680 \mathrm{C}$ interpreted as due to the presence of hematite (Fig. 4C).

Vector end-point demagnetization diagrams show the presence of characteristic remanent magnetization (ChRM) component directions oriented to the north and down (positive inclinations) or south and up (negative inclinations) that were isolated from $\sim 100 \quad \mathrm{C}$ up to $\sim 400 \mathrm{e} 600 \mathrm{C}$ (Fig. 5) in a total of 117 samples (detailed demagnetization temperature windows in Fig. 2D). These bipolar ChRM component directions, with mean angular deviation (MAD) values of usually less than 15 , are grouped in in situ (geographic) coordinates around a mean of declination $1 / 4 \quad 1.1 \mathrm{E}$, inclination $1 / 459.7 \quad\left(k^{1 / 4} 11.8, a 951 / 44.0\right.$; Fig. 6) and in tilt corrected

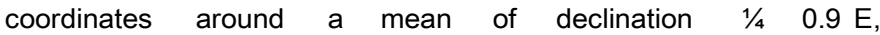
inclination $1 / 451.6 \quad\left(k \frac{1}{4} 11.3\right.$, a95 $1 / 44.1$; Fig. 6$)$.
The declination and inclination values of these ChRM component directions plotted versus stratigraphic depth (Fig. 2E and F) were used to calculate virtual geomagnetic pole (VGP) latitudes (Fig. 2G). VGP latitudes approaching p90 are interpreted as normal polarity and VGP latitudes approaching 90 as reverse polarity, thus defining a sequence of stratigraphically superposed normal and reverse magnetozones (Fig. 2H). The lower half of the section, from 0 to $\sim 50 \mathrm{~m}$, is characterized by reverse magnetic polarity interrupted by a normal polarity interval from 12 to $23 \mathrm{~m}$ (Fig. 2H). This part of the section is affected by faulting (Fig. $2 \mathrm{~A}$ ) that may have duplicated the stratigraphic record. The faulted levels comprising the lower normal polarity interval are moreover associated with high susceptibility and NRM intensity values (Fig. 2B and $C$ ) that could suggest chemical overprinting of the original magnetic signal. We therefore conservatively decided not to consider any further this lower part of the section. From $\sim 50$ to $92 \mathrm{~m}$ follows reverse polarity overlain by normal polarity up to $113 \mathrm{~m}$, in turn overlain by reverse polarity up to $223 \mathrm{~m}$, normal polarity up to about $235 \mathrm{~m}$, then again reverse polarity up to about $267 \mathrm{~m}$ and, finally, normal polarity that continues to the section top (Fig. 2H).

We interpreted this sequence of magnetozones by means of correlation to the Lourens et al. (2004) astrochronological polarity time scale that we anchored to the $d^{18} \mathrm{O}$ record of Shackleton (1995) (Fig. 7). The normal polarity interval found between 92 and $113 \mathrm{~m}$ is interpreted as a record of the Olduvai subchron (1.94e1.78 Ma; Fig. 7). This is supported by the first occurrence of $\quad H$. baltica at 98.3 m (Crippa et al., 2016), which at the Calabrian GSSP at Vrica is dated to around the top of the Olduvai (Cita et al., 2012), and of Arctica islandica at $103 \mathrm{~m}$. This latter has an extrapolated age of $\sim 1.85 \mathrm{Ma}$ in agreement with a radiometric $(\mathrm{He} / \mathrm{Th})$ age of $1.81 \pm 0.1 \mathrm{Ma}$ on corals from a level immediately above the first occurrence of A. islandica in the Santerno section (northern Apennines), as reported by Kukla et al. (1979) (see also Raffi, 1986).

The magnetochronologic interpretation of the reverse-normalreverse-normal polarity sequence observed from $113 \mathrm{~m}$ (top Olduvai) to the section top, which represents the main focus of the paper, is achieved with the aid of nannofossil data from three samples collected in the uppermost transitional-marine level at $275 \mathrm{~m}$ (Figs. 2A and 7; Table 1), not sampled by Crippa et al. (2016). Samples are largely dominated by reworked Cretaceous, Paleogene, and Neogene taxa. The most recent taxa, such as Helicosphaera sellii, small Gerphyrocapsa spp., and R. asanoi, provide an upper age limit 


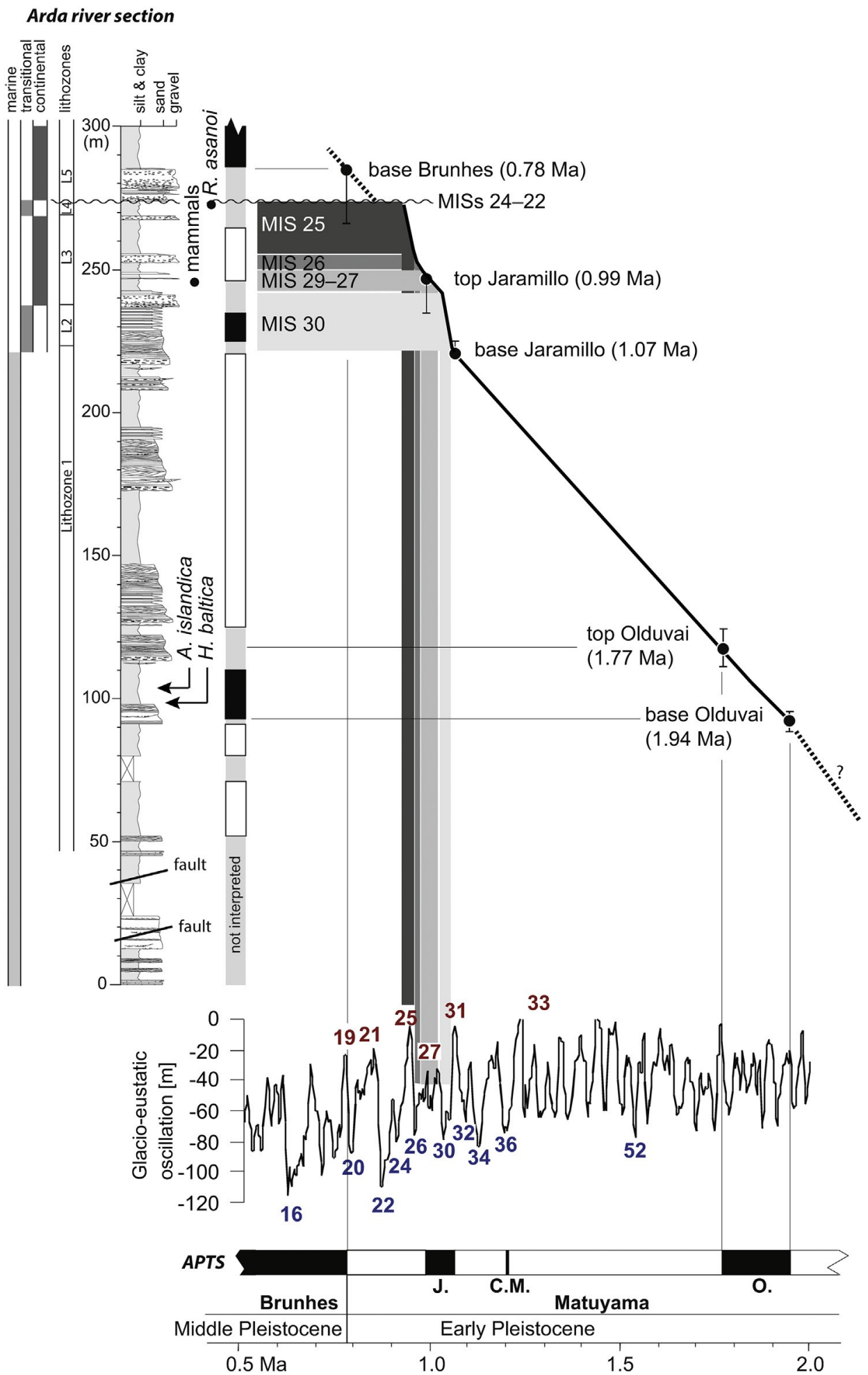

Figure 7. The Arda River section litho-magnetostratigraphy and key biostratigraphy correlated to the astrochronological polarity time scale (APTS) of Lourens et al. (2004) (J. 1/4 Jaramillo subchron, C.M. 1/4 Cobb Mountain subchron, O. 1/4 Olduvai subchron). The $d^{18} \mathrm{O}$ record of Shackleton (1995), scaled to the glacio-eustatic drop at the last glacial maximum time (Fairbanks, 1989), is placed aside the APTS. Even numbers in red above the glacio-eustatic curve represent warm marine isotope stages (MISs), while odd numbers in blue below the curve represent cold stages. Key fossil occurrences are also indicated on the Arda lithostratigraphic log. L2 $1 / 4$ lithozone 2; L3 1/4 lithozone 3; L4 $1 / 4$ lithozone 4; L5 $1 / 4$ lithozone 5. (For interpretation of the references to color in this figure legend, the reader is referred to the web version of this article.)

for the sampled level; in particular, the presence of R. asanoi, the youngest taxon recovered in the reworked assemblage, indicates terminus post quem sedimentation between 1.14 and $0.91 \mathrm{Ma}$ (Rio et al., 1990; Raffi, 2002). We therefore interpret the normal polarity interval from 223 to $\sim 235 \mathrm{~m}$ as a record of the Jaramillo subchron (1.07e0.99 Ma), and the normal polarity interval at the section top as a (partial) record of the Brunhes Chron with a base at $0.78 \mathrm{Ma}$ (Fig. 7), in agreement with previous studies indicating that 


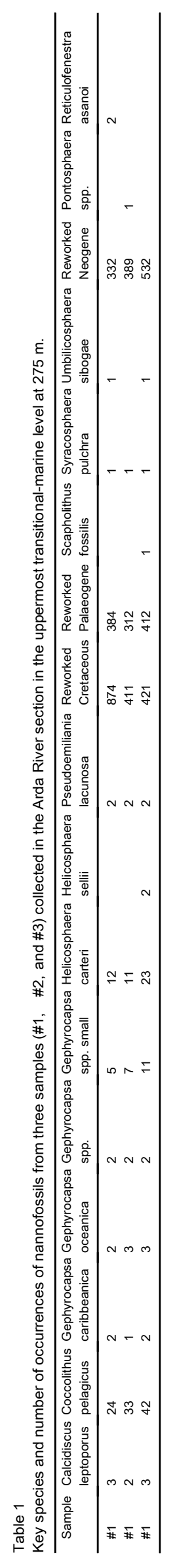

full and persistent continental sedimentation similar to that observed in these levels occurred in the greater Po basin during the Brunhes Chron (e.g., Muttoni et al., 2003; Scardia et al., 2012). The intervening reverse polarity intervals are interpreted as records of the Matuyama Chron (Fig. 7).

Five magnetochronologic tie points have therefore been used to erect an age model of sedimentation for the Arda River section: the base and top of the Olduvai (1.94 and $1.78 \mathrm{Ma}$, respectively), the base and top of the Jaramillo (1.07 and $0.99 \mathrm{Ma}$, respectively), and the MatuyamaeBrunhes boundary (0.78 Ma) (Fig. 7). As stated previously, the polarity stratigraphy below the base Olduvai has not been interpreted. According to the proposed age model, the long-term (average) sediment accumulation rate between the top of the Olduvai and the base of the Jaramillo is $\sim 15 \mathrm{~cm} / \mathrm{ky}(1 / 4150 \mathrm{~m} / \mathrm{Ma})$. The transition from marine to fully continental conditions, represented by the regressive sequence starting with littoral sandstones at $200 \mathrm{~m}$ and evolving into the first fluvial conglomerates at $237 \mathrm{~m}$, may correspond to the MIS 30 regression and lowstand at $\quad \sim 1.04$ Ma within the Jaramillo (Fig. 7).

The mammal bed at $245 \mathrm{~m}$ is approximately dated to the MIS 27 e29 interval centered at $\sim 0.99 \mathrm{Ma}$ (Fig. 7). This finding revises the age of the Early Galerian Colle Curti faunal unit, to which these mammals pertain, that was previously dated to the base of the Jaramillo (Coltorti et al., 1998). As pointed out in Muttoni et al. (2010), the magnetostratigraphy of the Colle Curti type section is difficult to evaluate because of the presence of pervasive normal polarity remagnetizations associated with iron sulphides (Coltorti et al., 1998). Finally, the uppermost transitional-marine level with R. asanoi is attributed to MIS $25(\sim 0.95 \mathrm{Ma}), \quad$ while the fluvial conglomerate at $275 \mathrm{~m}$ immediately above was presumably deposited during the profound glacioeustatic lowstand culminating with MIS 22 at $\sim 0.9 \mathrm{Ma}$, which marks the first most prominent continental glaciation of the Pleistocene in the Alpine-Po basin region (Muttoni et al., 2003; Scardia et al., 2006).

\section{Discussion}

We use data from the Arda River section in conjunction with data from the coeval Stirone River (Gunderson et al., 2013, 2014), Enza River (Gunderson et al., 2012) and Monte Poggiolo (Muttoni et al., 2011) sections to reconstruct the timing of the marineecontinental transition in the southern part of the greater Po basin (Fig. 8A and B). We excluded from discussion data from the Stirone River section (Fig. 8B) because the critical stratigraphic interval between the Olduvai and the Jaramillo is substantially reduced (only $20 \mathrm{~m}$-thick) probably due to the growth of the Salsomaggiore thrust between 1.8 and 1.0 Ma (Gunderson et al., 2012, 2013). Inspection of Figure $8 \mathrm{~A}$ reveals that the marinee continental transition was slightly diachronic: while marine conditions persisted at Monte Poggiolo in the early part of the post-Jaramillo Matuyama, in the western part of the southern Po basin, at Arda and Enza, littoral sediments were accumulating during MIS 30 within the Jaramillo. Continental to transitional conditions were first established along the entire $\sim 230 \mathrm{~km}$-long studied transect only at the MIS 22 lowstand and persisted during the ensuing MIS 22/MIS 21 sea level rise and MIS 21 high-stand at $\sim 0.85 \mathrm{Ma}$ (Fig. $8 \mathrm{~A}$ ).

A similar situation has been observed in several deep cores taken by the geological survey of Region Lombardy (RL cores) across the northern part of the Po basin (Scardia et al., 2006, 2012) (Fig. 8B). As Figure 8C suggests, while the western cores displayed continental sedimentation since the pre-Jaramillo Matuyama (e.g., RL3), it is only at and after MIS 22e20 that continental sedimentation was established in the more eastern cores (e.g., RL2, RL1). It appears therefore that a first major jump eastward of the coastline 


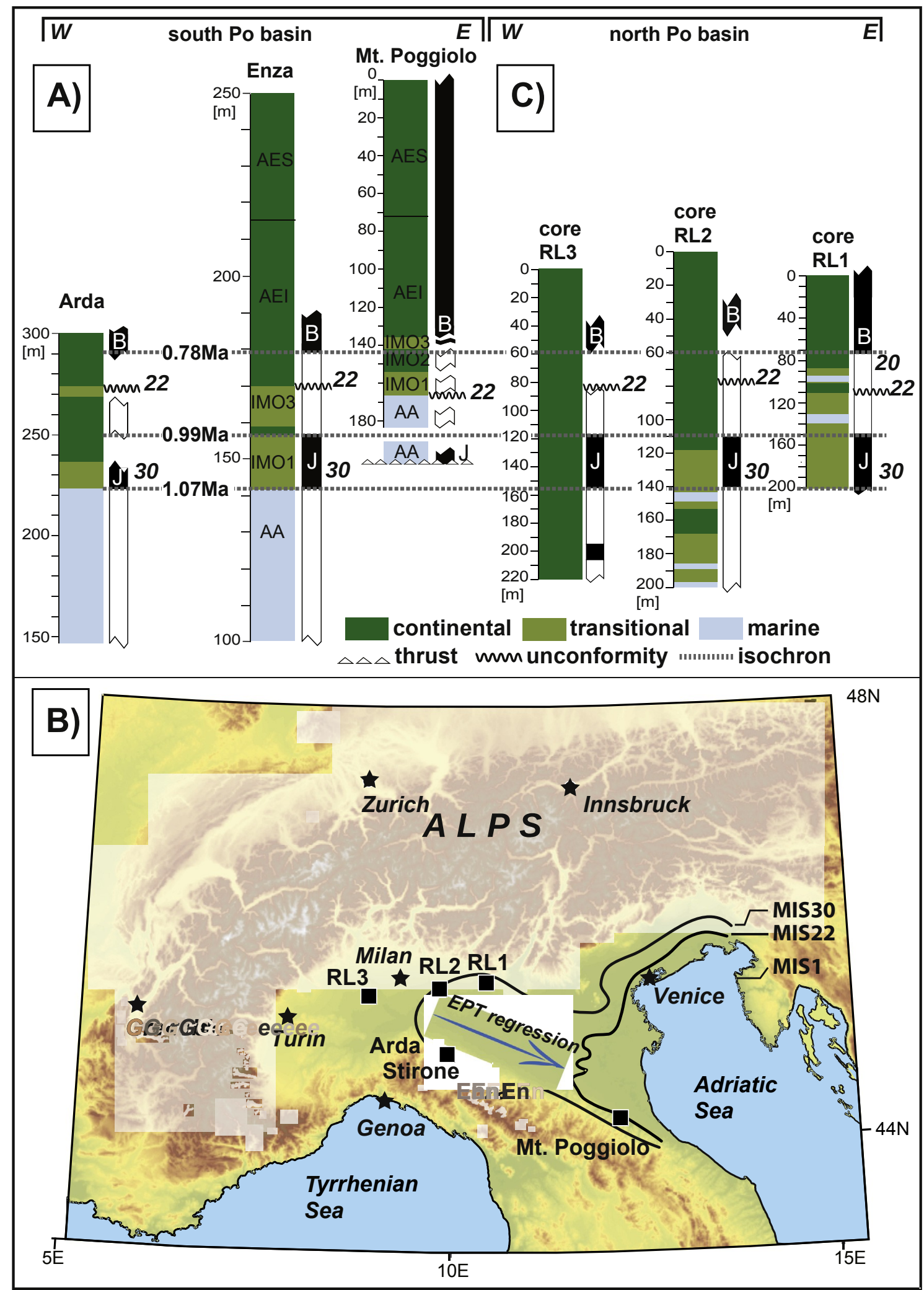

Figure 8. (A) Correlation of the litho-magnetostratigraphy of the Arda River section of this study with the Enza River (Gunderson et al.,

2014) and Monte Poggiolo (Muttoni et al. (2011) litho-magnetostratigraphies from the southern part of the Po basin. (B) Paleogeography of the Po basin at the first major regression of the coastline in consequence of the MIS 22 lowstand during the late Early Pleistocene climate turnover (EPT). The EPT regression coincided with the full opening of the Po (and Danube) Galerian mammal migration pathway as described in Muttoni et al. (2014). (C) Correlation of the litho-magnetostratigraphies of selected deep cores (RL1, RL2, and RL3) from the northern part of the Po basin (Scardia et al., 2006, 2012). On magnetostratigraphic logs, black is normal polarity and white is reverse polarity; B $1 / 4$ Brunhes Chron and J $1 / 4$ Jaramillo subchron (reverse polarity intervals between Brunhes and Jaramillo and below Jaramillo are records of the Matuyama Chron); $301 / 4 \mathrm{MIS} 30$ ( $1.05 \mathrm{Ma}), \quad 221 / 4 \mathrm{MIS} 22$ ( 0.87 Ma); $201 / 4 \mathrm{MIS} 20(\sim 0.80 \mathrm{Ma})$.

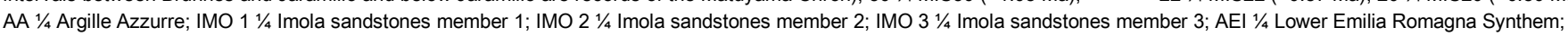
AES 1/4 Upper Emilia Romagna Synthem (see Scardia et al., 2006, 2012; Calabrese et al., 2009 for further descriptions of these units). 
was attained along the studied portion of the Po basin at the MIS 22 lowstand, which is represented in several cores by the so-called ' $R$ ' surface (or unconformity) that marks the progradation of highenergy alluvial fans from the southern Alps onto the Po basin (Muttoni et al., 2003; Scardia et al., 2006). MIS 22 represents the first major northern hemisphere continental glaciation of the Pleistocene (Shackleton and Opdyke, 1976; Berger et al., 1993; Shackleton, 1995; Head and Gibbard, 2005; Muttoni et al., 2003; Scardia et al., 2006, 2012) occurring during the so-called 'late Early Pleistocene climate turnover' (EPT, quoted in the literature also as 'late Early Pleistocene climate revolution' e EPR; Muttoni et al., 2014, 2015a).

The EPT coincided with a profound rejuvenation of the environment and the mammal fauna with the substitution of old Villafranchian by new Galerian elements (Palombo and Mussi, 2006; Manzi et al., 2011; Muttoni et al., 2014; Palombo, 2014). In particular, Muttoni et al. (2014) speculated that large mammals, and possibly hominins with them, may have migrated to Europe starting at around $0.9 \mathrm{Ma}$ because the EPT generated for the first time in the Pleistocene vast and exploitable ecosystems for African and Asian mammals especially along a conjunct Po-Danube gateway connecting southern Europe with the Balkans (see Figure 4 in Muttoni et al., 2014). These new environments were characterized by stable continental lowlands with open grassland vegetation and reduced woody cover during the onset of glacial/ interglacial transitions (starting with MIS 22/MIS 21) (see references to key pollen data and discussion in Muttoni et al., 2014). While the African and Asian immigrants may have exploited the Po-Danube gateway, other species may have migrated to southern Europe from north of the Alps or were simply redistributed across the continent; in that respect, there probably existed multiple entry points that collectively generated the Galerian turnover in the Italian peninsula (see also Palombo, 2014). In this respect, the hypothesis of the Po-Danube migration gateway (Muttoni et al., 2014) builds upon and complements earlier works on the mammal dispersal dynamics during the Pleistocene (Palombo and Mussi, 2006; Manzi et al., 2011; Palombo, 2014) because it provides the geological mechanism for the complex faunal turnover at the EPT.

The Arda mammal association, characterized by mixed Villafranchian and Early Galerian taxa attributed to MIS $27 \mathrm{e} 29$ at $\sim 0.99 \mathrm{Ma}$, seems to conform to this scenario whereby it registers the beginning of the rapid Galerian replacement of older Villafranchian taxa. Sus strozzii is a typical Villafranchian taxon, present in the Italian peninsula up to the Early Pleistocene pre-Jaramillo Farneta faunal unit (Gliozzi et al., 1997; Masini and Sala, 2007), while our data indicates its presence up to $\sim 0.99 \mathrm{Ma}$ at the top of the Jaramillo. It co-existed with Galerian 'newcomers' like Bison sp., a more evolved form than previous Eobison, and with $U$. dolinensis, which may have immigrated from central Europe where it was found at Untermassfeld (Germany) in levels attributed to MIS 31 at the base of the Jaramillo (Kahlke, 2006; Kahlke et al., 2011; Maul and Markova, 2007). It is however only when fully continental conditions were established in the Po basin during (and after) the EPT regression that the Galerian faunal turnover could take place in its full extent with a total rejuvenation of the fauna. At that time is recorded the entrance in the Italian peninsula of megaherbivores requiring a large dietary supply such as the straight-tusked elephant (Elephas antiquus), the steppe mammoth (Mammuthus trogontherii) and the red deer (Cervus elaphus acoronatus). These are among the most representative species of the far-traveled Galerian elements that migrated from Africa-Levant and Asia into Europe since around 0.9 Ma (Muttoni et al., 2014, 2015a and references therein), shortly after the Arda fauna with its mixed VillafranchianEarly Galerian European elements.

\section{Conclusions}

Our data from the Arda River section confirms that the progressive infill of the Po basin driving the transition from marine to fully continental environments was established only during the EPT since MIS 22 (Fig. 8) in the same magnetochronologic window that is believed to include also some of the best-dated sites with evidence of the first entrance in Europe of far-traveled megaherbivore immigrants (e.g., Muttoni et al., 2015a). This is also the same magnetochronologic window of the earliest stable peopling of Europe according to the critical analysis of key fossil sites from Iberia and Italy of Muttoni et al. (2014 and references therein), albeit we acknowledge that the late Earlyeearly Middle Pleistocene paleoanthropological record of Italy is still scanty, with only two well-dated sites at $\sim 850 \mathrm{ka}$ (Muttoni et al., 2011) and $600 \mathrm{ka}$ (Coltorti et al., 2005). The ongoing debate, recently summarized in Muttoni et al. (2015b), is centered on the question of whether the first peopling occurred in post-Jaramillo (and pre-Brunhes) times as a direct consequence of the EPT (Muttoni et al., 2013, 2014 2015a), or before the Jaramillo (e.g., Carbonell et al., 2008; ToroMoyano et al., 2013) during times of no particular climatic or ecologic turnover.

\section{Acknowledgments}

Two anonymous reviewers and the Editor are thanked for insightful comments. Lucia Angiolini is thanked for discussion on an earlier version of this manuscript. Christian Frigerio and Arianna Paschetto are thanked for assistance in the field and the lab.

\section{References}

Azzaroli, A., 1954. Filogenesi e biologia di Sus strozii e Sus minor (Revisione della fauna dei terreni fluvio-lacustri del Valdarno superiore, V). Paleontographia Italica 48 (18), 41e76.

Azzaroli, A., Mazza, P., 1992.The cervid genus Eucladoceros in the early Pleistocene of Tuscany. Palaeontographia Italica 79, 43e100.

Berger, W.H., Blickert, T., Schmidt, H., Wefer, G., 1993. Quaternary oxygen isotope record of pelagic foraminifers: site 806, Ontong Java Plateau. Proceedings ODP: Scientific Results 130, 381e395.

Bona, F., Sala, B2016. Villafranchian-Galerian mammal faunas transition in SouthWestern Europe. The case of the late early Pleistocene mammal fauna of the Frantoio locality, Arda River (Castell'Arquato, Piacenza, Northern Italy). Geobios. http://dx.doi.org/10.1016/j.geobios.2016.06.002.

Calabrese, L., Di Dio, G., Cibin, U., De Nardo, M.T., Di Giulio, A., Martelli, L., Martini, A., Pizziolo, M., Rogledi, S., Roveri, M., Vaiani, S.C.,2009. Note illustrative della Carta Geologica d'Italia alla scala 1:50.000. I.S.P.R.A.. Regione Emilia Romagna, Foglio 18, Salsomaggiore Terme.

Carbonell, E., Bermudez de Castro, J.M., Pares, J.M., Perez-Gonzalez, A., CuencaBescos, G., Olle, A., Mosquera, M., Huguet, R., van der Made, J., Rosas, A., Sala, R. Vallverdu, J., Garcia, N., Granger, D.E., Martinon-Torres, M., Rodriguez, X., Stock, G.M., Verges, J.M.,Allue, E., Burjachs, F..Caceres,I., Canals, A., Benito, A. Diez, C., Lozano, M., Mateos, A., Navazo, M., Rodriguez, J., Rosell, J., Arsuaga, J.L., 2008. The first hominin in Europe. Nature London 452 (7186), 465e469.

Channell, J.E.T., Poli, M.S., Rio, D., Sprovieri, R., Villa, G., 1994. Magnetic stratigraphy and biostratigraphy of Pliocene "Argille Azzurre" (northern Appennines, Italy). Palaeogeography, Palaeoclimatology, Palaeoecology 110,83e102.

Cita, M.B., Gibbard, P.L., Head,M.J., ICS Subcommission on Quaternary Stratigraphy, 2012. Formal ratification of the GSSP for the base of the Calabrian stage (second stage of the Pleistocene series, Quaternary system). Episodes 5 (3), 388e397.

Coltorti, M., Albianelli, A., Bertini, A., Ficcarelli, G., Laurenzi, M.A., Napoleonem, G. Torre, D., 1998. The Colle Curti mammal site in the Colfiorito areas (UmbroMarchean Apennine, Italy): geomorphology, stratigraphy, paleomagnetism and palynology. Quaternary International 47e48, 107e116.

Coltorti, M., Feraud, G., Marzoli, A., Peretto, C., Ton-That, T., Voinchet, P.,Bahain, J.J., Minelli, A., Hohenstein, U.T.,2005. New $40 \mathrm{Ar} / 39 \mathrm{Ar}$, stratigraphic and palaeoclimatic data on the Isernia la Pineta lower palaeolithic site, Molise, Italy. Quaternary International 131 (1), 11e22.

Crippa, G., Angiolini, L., Bottini, C., Erba, E., Felletti, F., Frigerio, C., Hennissen, J.A.I. Leng, M.J.,Petrizzo, M.R., Raffi, I., Raineri, G., Stephenson, M.H., 2016. Seasonality fluctuations recorded in fossil bivalves during the early Pleistocene: implications for climate change. Palaeogeography, Palaeoclimatology, Palaeoecology 446, 234e251. 
Fairbanks, R.G.,1989. A 17,000-year glacio-eustatic sea level record: influence of glacial melting rates on the Younger Dryas event and deep-ocean circulation. Nature 342, 637e642.

Fortelius, M., Mazza, P., Sala, B., 1993. Stephanorhinus (Mammalia: Rhinocerontidae) of the western European Pleistocene, with a revision of S. etruscus (Falconer, 1868). Palaeontographia Italica $80,63 e 155$.

García, N., Arsuaga, J.L.,2001. Ursus dolinensis: a new species of Early Pleistocene ursid from Trinchera Dolina, Atapuerca (Spain) 1/4 Ursus dolinensis: une nouvelle espece d'urside du PI eistocene inferieur de Trinchera Doline, Atapuerca (Espagne). Compte Rendues de l'Acałmie des Sciences e Series IIA e Earth and Planetary Science 332 (11), 717e725.

Garcia, N., 2004. New results on the remains of Ursidae from Untermassfeld: comparisons with Ursus dolinensis from Atapuerca and other early and middle Pleistocene sites. 18th International Senckenberg Conference in Weimar.

Gliozzi, E., Abbazzi, L., Argenti, P., Azzaroli, A., Caloi, L., Capasso Barbato, L., Di Stefano, G., Esu, D., Ficcarelli, G., Girotti, O., Kotsakis, T., Masini, F., Mazza, P., Mezzabotta, C., Palombo, M.R., Petronio, C., Rook, L., Sala, B., Sardella, R., Zanalda, E., Torre, D., 1997. Biochronology of selected mammals, molluscs and ostracods from the middle Pliocene to the late Pleistocene in Italy; the state of art. Rivista Italiana di Paleontologia e Stratigrafia 103 (3), $\quad 369$ e387.

Gunderson, K., Kodoma, K.P., Anastasio, D.J., Pazzaglia, F.J.,2012. Rock-magnetic cyclostratigraphy for the late Plioceneeearly Pleistocene Stirone section, northern Appennine mountain front, Italy. Geological Society of London, Special Publications 373, 1e16.

Gunderson, K., Anastasio, D.J.,Pazzaglia, F.J.,Picotti, V., 2013. Falut slip rate variability on $10{ }^{4} \mathrm{e} 10^{5}$ time scales for the Salsomaggiore blind thrust fault, Northern Appennines, Italy. Tectonophysics 608, 356e365.

Gunderson, K., Pazzaglia, F.J.Picotti, V., Anastasio, D.A., Kodama, K.P.,Rittenour, T., Frankel, K.F.,Ponza, A., Berti, C., Negri, A., Sabbatini, A., 2014. Unraveling tectonic and climatic controls on synorogenic growth strata (Northern Appennines, Italy). Geological Society of America Bulletin 126 (3e4), 532e552.

Head, M.J., Gibbard, P.L.,2005. EarlyeMiddle Pleistocene transitions: an overview and recommendation for the defining boundary. In: Head, M.J., Gibbard, P.L. (Eds.), EarlyeMiddle Pleistocene Transitions: the LandeOcean Evidence, vol. 247. Geological Society, London, pp. 1e18. Special Publication.

Kahlke, R.-D., 2006. Untermassfeld e a late Early Pleistocene (Epivillafranchian) fossil site near Meiningen (Thuringia, Germany) and its position in the development of the European mammal fauna. British Archaeological Reports, International Series 1578, 1 e144.

Kahlke, R.-D., 2007. Late early Pleistocene European large mammals and the concept of an Epivillafranchian Biochron. Courier Forschunginstitut Senckenberg 20 (259), 265e278.

Kahlke, R.-D., García, N., Kostopoulos, D.S., Lacombat, F., Lister, A.M., Mazza, P., Spassov,N., Titov, V.V., 2011. Western Palaearctic palaeoenvironmental conditions during the Early and early Middle Pleistocene inferred from large mammal communities, and implications for hominin dispersal in Europe. Quaternary Science Reviews 30 (11), 1368e1395.

Kostopoulos, D.S., 1997. The Plio-Pleistocene artiodactyls (Vertebrata, Mammalia) of Macedonia 1. The fossiliferous site "Apollonia-1", Mygdonia basin of Greece. Geodiversitas 19 (4), 845e875.

Kukla, G., Collins, B.P.,Blender, M.L., 1979. Radiometric age of the Arctica islandica boundary in Italy, 2 M.Y. Annales geologiques des Pays Helleniques, hors series 2, $699 \mathrm{e} 709$.

Lacombat, F.,2006. Mophological and biometrical differentiation of the teeth from Pleistocene species of Stephanorhinus (Mammalia, Perissodactyla, Rhinocerotidae) in Mediterranean Europe and the Massif central, France. Palaeontographica Abteilung A Band 274, 71e111.

Lourens, L.J.,Hilgen, F.J.Laskar, J., Shackleton, N.J.,Wilson, D., 2004. The Neogen Period. In: Gradstein, F.M., Ogg, J.G.,Smith, A.G. (Eds.), A Geologic Time Scale 2004. Cambridge University Press, Cambridge, pp. 409e440.

Manzi, G., Magri, D., Palombo, M.R., 2011. Early-Middle Pleistocene environmental changes and human evolution in the Italian peninsula. Quaternary Science Reviews 30, 1420e1438.

Mary, C., laccarino, S., Courtillot, V., Besse, J., Aissaoui, D.M., 1993. Magnetostratigraphy of Pliocene sediments from the Stirone River (Po valley). Geophysical Journal International 112, 359e380.

Masini, F., Sala, B., 2007. Large- and small-mammal distribution patterns and chronostratigraphic boundaries from the late Pliocene to the middle Pleistocene of the Italian peninsula. Quaternary International 160 (1), 3e56.

Maul, L.C.,Markova, A.K., 2007. Similarity and regional differences in Quaternary arvicolid evolution in central and eastern Europe. Quaternary International 160 (1), 81e99.
Musil, R., 2001. Die Ursiden-Reste aus dem Unterpleistozan von Untermassfeld. In: Kahlke, R.D. (Ed.), Das Pleistozan von Untermassfeld bei Meiningen (Thuringen). Romisch-Germanisches Museum Mainz, Mainz 2, pp. $633 e 658$.

Mutti, E., Tinterri, D., di Biase, D., Fava, L., Mavilla, N., Angella, S., Calabrese, L., 2000. Delta-front facies associations of ancient flood dominated fluvio-deltaic systems. Revista de la Sociedad Geologica de Espana 13 (2), 165e190.

Muttoni, G., Carcano, C., Garzanti, E., Ghielmi, M., Piccin, A., Pini, R., Rogledi, S., Sciunnach, D., 2003. Onset of major Pleistocene glaciations in the Alps. Geology 31, 989e992.

Muttoni, G., Scardia, G., Kent, D.V., 2010. Human migration into Europe during the late early Pleistocene climate transition. Palaeogeography, Palaeoclimatology, Palaeoecology 296, 79e93.

Muttoni, G., Scardia, G., Kent, D.V., Morsiani, E., Tremolada, F., Cremaschi, M., Peretto, C., 2011. First dated human occupation of Italy at $\sim 0.85$ Ma during the Late Early Pleistocene climate transition. Earth and Planetary Science Letters $307,241 \mathrm{e} 252$.

Muttoni, G., Scardia, G., Kent, D.V., 2013. A critique of evidence for human occupation of Europe older than the Jaramillo subchron ( 1 Ma): comment on 'The oldest human fossil in Europe from Orce (Spain)' by Toro-Moyano et al. (2013). Journal of Human Evolution 65, $746 \mathrm{e} 749$.

Muttoni, G., Kent, D.V., Scardia, G., Monesi, E., 2014. Migration of hominins with megaherbivores into Europe via the Danube-Po gateway in the late Matuyama climate revolution. Rivista Italiana di Paleontologia e Stratigrafia 120 (3), $351 \mathrm{e} 365$.

Muttoni, G., Scardia, G.,Dimitrijevi c, V., Kent, D.V., Monesi, E., Mrdjic, N., Kora c, M., 2015a. Age of Mammthus trogontherii from Kostolac, Serbia, and the entry of megaherbivores into Europe during late Matuyama climate revolution. Quaternary Research 84 (3), 439e447.

Muttoni, G., Kent, D.V., Scardia, G., Martin, R.A., 2015b. Bottleneck at Jaramillo for human migration to Iberia and the rest of Europe. Journal of Human Evolution 80, 187 e190.

Palombo, M.R., Mussi, M., 2006. Large mammal guilds at the time of the first human colonization of Europe: the case of the Italian Pleistocene record. Quaternary International 149, 94e103.

Palombo, M.R., 2014. Deconstructing mammal dispersal and faunal dynamics in SW Europe during the Quaternary. Quaternary Science Review 96, 50e71.

Pinti, D., Quidelleur, X., Lahitte, P., Aznar, C., Chiesa, S., Gillot, P.Y., 2001. K-Ar dating of an Early Middle Pleistocene distal tephra in the interglacial varved succession of Pianico e Sellere (southern Alps, Italy). Earth and Planetary Science Letters 188, 1 .

Raffi, S., 1986. The significance of marine boreal molluscs in the Early Pleistocene faunas of the Mediterranean area. Palaeogeography, Palaeoclimatology, Palaeoecology 52, 267e289.

Raffi, I., 2002. Revision of the early-middle Pleistocene calcareous nannofossil biochronology (1.75-0.85 Ma). Marine Micropaleontology 45, $25 e 55$.

Rio, D., Raffi, I., Villa, G., 1990. Pliocene-Pleistocene calcareous nannofossil distribution patterns in the western Mediterranean. In: Proceedings of the Ocean Drilling Program Scientific Results 107, Ocean Drilling Program. Texas A\&M University, College Station, Texas,pp. 513e533.

Sala, B., 1986. Bison schoetensacki Freud. from Isernia la Pineta (early MidPleistocene e Italy) and revision of the European species of bison. Palaeontographia Italica $74,113 \mathrm{e} 170$.

Scardia, G., Muttoni, G., Sciunnach, D., 2006. Subsurface magnetostratigraphy of Pleistocene sediments from the Po plain (Italy): constraints on rates of sedimentation and rock uplift. Geological Society of America Bulletin 118 (11e12), $1299 \mathrm{e} 1312$.

Scardia, G., De Franco, R., Muttoni, G., Rogledi, S., Caielli, G., Carcano, C., Sciunnach, D., Piccin, A., 2012. Stratigraphic evidence of a middle Pleistocene climate-driven flexural uplift in the Alps. Tectonics 31 (6), 1e18.

Shackleton, N.J., Opdyke, N.D., 1976. Oxygen-isotope and paleomagnetic stratigraphy of Pacific core V28-239, late Pliocene to latest Pleistocene. Memoir Geological Society of America 145, 449e464.

Shackleton, N.J., 1995. New data on the evolution of Pliocene climate variability. In: Vrba, E., Denton, G.H., Partridge, T.C., Burckle, L.H. (Eds.), Paleoclimate and Evolution, with Emphasis on Human Origins. Yale University Press, New Haven, pp. $242 \mathrm{e} 248$.

Toro-Moyano, I., Martinez-Navarro, B., Agusti, J., Souday, C., Bermùdez de Castro, J.M., Martin on-Torres, M., Fajardo, B., Duval, M., Falgueres, C., Oms, O., Pares, J.M., Anadon, P., Julia, R., Garcia-Aguilar, J.M., Moigne, A.M., Espigares, M.P., Ros-Montoya, S., Palmqvist, P. 2013. The oldest human fossil in Europe, from Orce (Spain). Journal of Human Evolution 65 (1), 1 e9. 